\title{
Usefulness of Natural Starters in Food Industry: The Example of Cheeses and Bread
}

\author{
Demarigny Yann*, Gerber Pauline \\ BIODYMIA, ISARA-Lyon, 23, rue Jean Baldassini, 69364, Lyon, France \\ Email: ${ }^{*}$ ydemarigny@isara.fr
}

Received 24 June 2014; revised 28 July 2014; accepted 10 August 2014

Copyright (C) 2014 by authors and Scientific Research Publishing Inc.

This work is licensed under the Creative Commons Attribution International License (CC BY). http://creativecommons.org/licenses/by/4.0/

(c) (i) Open Access

\begin{abstract}
Natural starters have been extensively used for many centuries to make many different fermented food products from different raw materials: Milk, meat, roots, vegetables, etc. The industrialisation of food production at the end of the $19^{\text {th }}$ century necessitated the use of regular selected starters to standardize the organoleptic characteristics of the final product. As a consequence, during the $2^{\text {th }}$ century, there was a decline in the use of natural starters in Western countries except in the production of local cheeses or sourdough breads. The beginning of this new millennium has witnessed a deep change in consumer demand, in pursuit of quality, safety and pleasure. In this context, natural starters could, in the future, play an important role in the development of fermented products. However, food producers and researchers have first to cope with fundamental problems in the understanding of these complex ecosystems. The dynamic evolution of the microbial population inside the natural starter (its resilience, its genetic and physiological aptitudes) and the consequences on the product are still partially unknown. This document reviews a broad range of articles concerning the use of natural starters with a specific focus on cheeses and breads, and discusses the major stakes for local food production and the consumption of typical products.
\end{abstract}

\section{Keywords}

Natural Starter, Cheese, Bread, Sourdough, Food Ecosystem

\section{Introduction}

Before the World Trade Organization's Millennium Round, Roger (2000) [1] proposed that the concept of "typicality" be given international recognition. According to Sylvander (2007, cited by [2]), "the typicality of a given agricultural produce can be defined as the property of belonging to a particular type, defined and recog-

${ }^{*}$ Corresponding author. 
nised as such by a specific human group, the different members of which have acquired areas of knowledge or know-how relative to their role in the production process. Know-how, then, as regards the setting up of the process, and the making, testing and tasting of the product. Typicality must not be mistaken for conformity with a norm; it allows for internal variations within the type. Among the diverse manifestations of typicality, that which is linked to the land (notion of terroir) is a particular construction that aims to materialise the effect of the land on a given product”. Behind quality labels and Protected Geographical Status (PGS) for food stuffs (such as Protected Designation of Origin and Protected Geographical Indication), there are highly important cultural and social aspects to be taken into account in order to understand the deeper meaning of products. Throughout Europe, traditional food product manufacturing is an ongoing practice.

In many countries, however, traditional foods can also be seen as "innovation backwardness without real quality improvement” and as such, as a form of protectionism. Moreover, the price of such products is quite high because the norms governing their manufacture are more restrictive, which creates difficult retailing conditions abroad. However, know-how and "terroir" contribute to giving these typical products an emotional value. Typicality is a wide-ranging concept taking into account sensory quality (taste, odour, texture), specific processes (breeding, feeding system, cheese-making, ripening), edaphism (environmental conditions, flora of the forage), historical and social aspects and all the relationships between these features [3]. Nowadays, establishing a link between these traditional practices and the typicality (in the restrictive meaning of "sensory quality") of a food product is a major stake and can be seen as a big challenge for the coming years. Among these practices, backslopping, for instance, is of interest for cheese and bread makers.

This document presents an overview of available information of backslopping practices and the use of natural starters to make fermented foods, with a specific focus on cheeses and, to a lesser extent, sourdough breads.

\section{Description, Origin, Function: The Place of Natural Starters in Traditional Food Systems}

\subsection{What Are Starters?}

Leaven products are pre-fermented. They are composed of a great deal of microorganisms encompassing different types (bacteria, yeast, moulds) and species. Starters are obtained either by selection or naturally. Selected starters include a limited number of strains carefully chosen for specific technological activities, i.e. acidification or aroma production. They are dedicated to the first steps of the food making process or ageing. Their regular use leads to standardized final products in terms of organoleptic properties—savour, aroma, aspect [4] [5].

\subsection{What Are Natural Starters (NS)?}

NS, also called wild or indigenous starters, are made up of complex microflora-especially lactic acid bacteria (LAB) but also yeasts and moulds-that can originate from various sources (environment, raw materials, processing tools...). These microorganisms form complex ecosystems where they can easily become associated with each other [6]. NS are mainly linked to backslopping, but they can also result from natural acidification by wild LAB coming from the raw materials (natural acidifications are seldom observed in cheese-making in the south of Europe). Natural seeding is also seen for many wines: the bacteria Enococcus œni frequently originates from the grape berries [7]. Backslopping consists in keeping a sample of the batch of the day to inoculate the raw food in the subsequent batch [8]. The culture can be made at room temperature (farm house made cheeses) or follow a temperature gradient as a consequence of a slow cooling (hard cheeses). The making and the nature of the sample used to propagate the starter depend on the type of product made: cheese whey, an item of fermented meat (dry sausages) or sourdough (bread). Backslopping greatly increases the acidification rate during the first stages of the curd fermentation (which can otherwise take more than 48 hours when spontaneous). Day after day, the species most adapted to the food, the process and the environmental conditions, are selected [4].

\subsection{History in a Nutshell}

The use of fermentations most probably appeared simultaneously many centuries ago all over the world [4] [9]. Fermentation is associated with five functions which explain why it has been used so substantially: preservation over time, detoxification, diet diversification, taste improvement and the reduction in cooking time [10]. Any 
raw food material can be put aside for subsequent fermentations: grains (wheat, rice, corn, millet, sorghum...), fruits (grape), vegetables (cabbage), legumes (soya), roots (cassava), milk, meat and fish. Through fermentation, food products can take many different forms: gruels, pastes, breads, beverages (alcoholic or not), cheeses [11].

If today the preservation of microorganisms involved in fermentations mainly relies on selected starters-especially in Western countries_traditionally, inoculums could be prolonged by backslopping or dehydration, or they could be carried in a flask or on a porous vegetal material [4]. In Africa and Asia for instance, backslopping is frequently used for traditional cereal products. Mawe, a corn gruel from Benin, is fermented by heterofermentative Lactobacilli and yeasts. Spontaneous fermentation takes place after grinding and soaking, and can be enhanced with an "inoculation belt" which carries microorganisms over from the previous fabrication. Pito, a beer from Ghana, is produced in the same way [4].

In Mongolia, the traditional manufacture of mare fermented milk koumiss has always made use of backslopping. Each nomadic tribe has its own process. Iakoutes put milk into a goatskin flask or a wooden vat and regularly beat it with a wooden rod, which has proven to favour fermentation. Regularly, a part of the sour milk obtained is put aside for the family’s own consumption and replaced by fresh milk to continue the fermentation process. Kirghizes and Bachkirs put milk into a horse skin leather bag and inoculate it with dry koumiss. Churning is done by hand or by hanging the goatskin container to the saddle [12].

Vegetable fermentation using backslopping is visible, for instance, in the production of sauerkraut. The brine from the previous fermentation is added to fresh grated and salted cabbage [13]. But the West African Dawadawa, a fermented product from soya or locust beans, is another example of legume fermentation obtained by backslopping. To prepare the inoculums, a mix of materials from the previous fabrication, soya or locust beans, cereals and vegetables, is dehydrated for preservation until subsequent use [11].

In the case of meat and fish products, backslopping fermentation is less usual. For meats such as dried sausages, a meat mix reserved from the current batch can be kept to help subsequent fermentation. But in Western countries, this practice has become rare. Brines of fermented salted fish such as Thai plasom can also be used as inoculums for the next batch [14].

Fermentation substrates are numerous, and, for a specific raw material, there may be various backslopping techniques depending on the manufacturing process. Consequently, there is a significant diversity in fermented products.

\subsection{Backslopping Techniques: The Example of Sourdoughs and Cheeses}

Sourdough bread is obtained by backslopping. The first step in this kind of bread making is to elaborate the mother sourdough with a mix of flour (rye, wheat) and water (using water in which dry fruits or bran have been soaked can bring an extra source of organic sugar). This mix is fermented and refreshed on a daily basis with flour and water. After a second phase of fermentation, the sourdough is ready to be added to the bread dough [15]. Every day, a dough roll is saved to ferment the next bread mix. "Type I" sourdough goes through continuous backslopping and refreshments under an ambient temperature while “Types II and III” are ready-to-use industrial sourdoughs [16]. However, from baker to baker, the way to prolong the sourdough can change greatly. This explains the variety of sourdough breads obtained, each displaying a particular aromatic balance.

Backslopping in cheese making is frequently used for goat milk cheeses. For instance, over the 14 French goat cheese having acquired a Protected Designation of Origin certificate (DOP or AOP in French), backslopping is a requirement as laid down in the product specifications of six of them, namely: Picodon, Rocamadour [17], Pélardon, Charolais, Mâconnais and Rigotte de Condrieu. Milk used in the elaboration of Cabécou, a goat cheese with a quality label (Label Rouge) is also inoculated exclusively with a natural whey starter (NWS). But we have observed that, in reality, this practice also concerns a great part of French farmers who make their own cheese independently of any label. In some hard cheese processes, whey can be adjoined to milk as natural starter in addition to rennet. This technology has been extensively studied in Comté cheese [18], Grana Padano [19] and Parmigiano Reggiano. Specifications for some semi-hard cheeses, such as the French DOP Abondance, mention the optional addition of NWS. However, the risks of contamination by Staphylococcus being acute, few cheese makers do this. In South Italia, stretched cheese technology based on backslopping is widespread. It is the case for Mozzarella di Bufala Campana [20] [21], Scamorza Altamurana [22] and Caciocavallo Silano [23].

To obtain a NWS, the whey from the draining of the curd is saved, incubated until pH is low enough (if nec- 
essary), cooled down or directly stored at room temperature ready to inoculate the next batch. Depending on the type of curd desired, the NWS can be completed or not with rennet to finish the clotting step. There are different practices associated with NWS. The simplest way consists in combining the milk from the evening's milking with the following morning's milk and then to inoculate the mix with NWS. Milk from the evening's milking can also be inoculated with NWS then set aside and mixed with the following morning's milk. It is possible to obtain a natural starter by incubating fresh milk over several hours at an ambient temperature. All these practices are frequently referred to in France as "prématuration" (pre incubation). The problem is the high risk of contamination, since the milk is raw. Occasionally, as the microflora is not controlled at all, acidification can be very long or not high enough to limit the development of pathogenic or spoiling bacteria while ripening flora is at quite a low level. Recently, another way of obtaining a natural starter has been proposed: UHT milk is incubated in the dairy plant in order to be contaminated by the air microbes (spores, bacteria hanging on dust particles or microscopic drops). However, the lack of control over the unwanted flora is here also the main drawback [24].

The cheese technology affects the composition and nature of the NWS at two levels. First, the type of curd determines the initial physico-chemical characteristics of the whey. Whey originating from rennet coagulation (such as hard cheese whey) initially registers a pH higher than 6.3. Dalmasso (2009) [25], in a model "tomme de vache" type cheese, used such a material. The whey was at $30^{\circ} \mathrm{C}$ until $\mathrm{pH}$ reached 4.7 , then refrigerated until use the following day. Whey obtained from lactic acid coagulation (farmhouse made goat milk cheeses for instance) is much more acidic; its $\mathrm{pH}$ may reach 4 . It is also richer in free minerals (Ca, $\mathrm{P}$ ) because acidity dissociates casein micelles. Dalmasso (2009) [25] in a goat milk cheese model (lactic acid coagulation with the addition of a small amount of rennet), obtained acidic curds ( $\mathrm{pH} 4.7$ ); the whey was directly refrigerated for further use.

The incubation temperature is also a fundamental parameter in selecting the desired microorganisms (mesophilic or thermophilic). In Scamorza Altamurana technology, whey is heated up to $40^{\circ} \mathrm{C}-42^{\circ} \mathrm{C}$ then cooled to allow thermophilic bacteria to develop (such as Streptococcus thermophilus) which can survive the curd cooking step [26]. In Rocamadour, whey is incubated to ambient temperature $\left(20^{\circ} \mathrm{C}-24^{\circ} \mathrm{C}\right)$ to allow the development of mesophilic LAB and decrease the pH [17]. Salvadori del Prato (2002) [27] indicated that in grana cheeses, the whey is removed at $54^{\circ} \mathrm{C}-55^{\circ} \mathrm{C}$ and allowed to cool down for many hours. As a consequence of the thermal gradient, the whey microbiota goes through different phases. While thermophilic lactic acid bacteria start the acidification, their action is completed by mesophilic lactobacilli as the temperature decreases. The influence of the temperature and duration of incubation on dominant flora has also been demonstrated for sourdough [28]. In a sourdough cultured at $30^{\circ} \mathrm{C}$ and $37^{\circ} \mathrm{C}$ during $24 \mathrm{~h}$, Lactobacillus fermentum was dominant whereas at $23^{\circ} \mathrm{C}$ it was no longer detected; Leuconostoc citreum, a less common bacteria well adapted to lower temperatures, was the dominant population. The lengthening of the sourdough culture duration to $48 \mathrm{~h}$ at $30^{\circ} \mathrm{C}$ allowed two species to dominate, Lactobacillus fermentum and $L b$ plantarum. At a given temperature, competitive species seemed to grow more easily in a refreshed medium ( $L b$ fermentum). Some other species preferred an acidic and less nutritive environment ( $L b$ plantarum), developing only when conditions became too harsh for the others.

\section{Impact of Natural Starters on Fermented Food Products}

\subsection{Biodiversity and Dynamics}

Natural starters are microbial ecosystems. They are complex and continuously changing. They are composed of many microbial genders, species, subspecies and strains. These microorganisms come from different sources (e.g. the environment, raw materials, equipment, the producers themselves). Natural starters are thus numerous and various. The structure of the matrix is also very important: a liquid starter (NWS for instance) allows the bacteria to move inside whereas a thicker material (bread roll) obstructs the microbes' movement. In the first case, the ecosystem can be considered as open (to microbial exchanges); in the second case, it is rather closed. This contributes to making the ecosystem more complex. However, complexity also comes from abundant bacterial associations and interactions favoured by the structure of the matrix [25]. These interactions can be genetic, nutritional or metabolic in nature [29]. As the medium is changing, interactions between microorganisms may help them to adapt.

Microbial collective behaviour in natural starter is quite obvious (e.g. acidification, production of aromatic and textural compounds), especially if we focus on macroscopic features. Nevertheless, the role played by individual microbes and the interactions between them, at whatever level we observe them (populations, species, 
strains), are still largely unknown.

\subsubsection{Biodiversity in Raw Materials}

In technologies relying on the use of backslopping, raw material microflora frequently participates in the acidification and the ageing steps of the food. These adventitious microflora progressively enrich the starter. In the case of cheeses for example, Dalmasso et al. (2008) [30] observed the progressive invasion of the NWS (and correlatively of the cheeses) by Enterococcus and Lactobacillus populations, even if they never dominated lactococci.

Contamination sources are numerous. Among them, teat skin, air in the stable and in the milking parlour and how the animals are fed contribute to enhancing the concentration and the diversity of microorganisms in the raw milk. For instance, two major sources of milk contamination by LAB have been identified: the teat skin and milking machine biofilms [31] [32].

The microbial composition of milk varies qualitatively and quantitatively depending on the milking day (Dalmasso et al., 2008) and the season [33] [34]. Mesophilic and aerobic bacteria, Corynebacterium and Micrococus are nearly always found [35]. The presence of wild LAB (Lactococcus, Lactobacillus, Enterococcus, and Leuconostoc) and propionic acid bacteria is also observed but at varying levels. Unwanted bacteria (e.g. spoiling, Pseudomonas, or pathogenic, Listeria, Staphylococcus) are, seldom, also present in milk.

\subsubsection{Natural Starter Composition}

From a general point of view, the type of microorganisms found in natural starters can be very diverse. This is explained by the origin of the raw material, the climate, the technology used, etc. Table 1 presents some examples of starter composition for some products from different origins. As it can be observed, starters can be obtained either by spontaneous fermentation — the raw material is only seeded by adventitious microorganisms—or by backslopping (and in some cases by the combine use of the two ways).

Whey ecosystem is composed of microflora coming from raw milk (whose microflora results from different sources as indicated above), the microflora of the preceding NWS (which depends on the process, the practice and the individual cheese-maker) and the environment (air, equipment, dairy plant) [25]. Even though lactococci, enterococci or lactobacilli are more frequently found in natural starters, other bacterial genus can appear such as Bifidobacterium and Streptococcus thermophilus. Besides, starter can combine bacteria, moulds and yeasts, as in the case of some fermented milk (koumiss, kefir) [4] [6].

In the case of hard cheeses, dominant LAB are thermophilic. Numerous lactobacilli including Lactobacillus helveticus, Lb fermentum, Lb delkrukii subsp. bulgaricus/lactis and Streptococcus thermophilus belong to this group [36] [37]. These bacteria are selected and favoured by the high temperature at which the curd is cooked (more than $50^{\circ} \mathrm{C}$ ).

In Rocamadour technology (a French goat milk cheese), Demarigny et al. (2006) [17] showed that the NWS were mainly composed of Lactococcus (around $9 \log (\mathrm{cfu}) / \mathrm{mL}$ ) and especially Lc lactis subsp. cremoris and $L c$ lactis subsp. lactis biovar. diacetylactis. Leuconostocmesenteroïdes subsp. mesenterö̈des and Lnmesenteroïdes subsp. cremoris were also present. Similar results were obtained in a goat milk cheese model using primarily lactic acid coagulation with the addition of a small amount of rennet, made over the course of eight days. Dalmasso (2009) [25] highlighted a high population of Lactococcus lactis subsp. lactis in whey starters (around 9.4 $\log (\mathrm{cfu}) / \mathrm{mL})$. They probably came from the initial starter. Other LAB were not found at significant levels. Leuconostocs, which originated from "raw milk" (in fact from the reseeded model milk RMM used, i.e. a pasteurized milk seeded with wild LAB), were present in almost all the NWS but at low levels (3.6 log (cfu)/mL). Therefore, natural starter bacteria come from different origins. In a "tomme de vache" type cheese (pressed and uncooked curd), made over ten successive days, Dalmasso (2009) [25] observed the dominance of the Lactococcus population in the NWS $(9.2 \mathrm{log}(\mathrm{cfu}) / \mathrm{mL})$. Other LAB-lactobacilli, enterococci-were present at low levels. Raw milk microflora seemed to be subdominant in model NWS, but this does not mean that they can be neglected, especially during the ripening stage. They are difficult to detect because of the presence of dominant bacteria or because the parameters of the study are not really suitable for seeking them out [34].

In sourdoughs used to make bread, the process is different from those we find in cheese-making. Traditional sourdoughs are generally cultured continuously. The frequent removal of a portion of the dough (to make bread) is compensated by the addition of water and flour. The ecosystem obtained includes bacteria from the sourdough itself and wild bacteria from wheat, water and the plant (or bakery) environment (equipment, air and work sur- 
Table 1. Example of fermented products obtained by spontaneous fermentation or by the use of natural starters. LAB: lactic acid bacteria; Ln: Leuconostoc; Lb: Lactobacillus; Pc: Pediococcus; Ec: Enterococcus; S: Saccharomyces.

\begin{tabular}{|c|c|c|c|c|}
\hline Product & Origin & Raw Material & Main Microflora & Type of Fermentation \\
\hline Pain & Different origins & Grain flour & $\mathrm{LAB}$ & Natural starter \\
\hline Fromage & Different origins & Milk & Lactobacillus spp, Lactococcus spp, Ln spp. & Natural starter \\
\hline Kefir & Different origins & Milk & LAB, yeasts & Natural starter \\
\hline Chocolate & South America & Cacao beans & LAB, yeasts & Spontaneous \\
\hline Kimchi & Corea & Radish, cabbage & $\begin{array}{c}\text { LAB (Lb plantarum, Lb brevis), Streptococcus faecalis, Ln } \\
\text { mesenteroides, Pediococcus pentosaceus }\end{array}$ & Spontaneous \\
\hline Kivunde & Tanzania & & $\mathrm{LAB}$ & \\
\hline Fufu & Nigeria & & LAB, Bacillus, coliforms, Enterococcus, Klebsiella, Candida & \\
\hline Attieke & Ivory Coast & Cassava & LAB (Ln mesenteroïdes subsp. mesenteroïdes, Ec faecalis) & $\begin{array}{l}\text { Spontaneous or natural } \\
\text { starters }\end{array}$ \\
\hline Gari & West Africa & & LAB, Alacaligenes, Corynebacterium, Lb plantarum & \\
\hline Agbelina & $\begin{array}{l}\text { Ivory Coast } \\
\text { Ghana }\end{array}$ & & Lbs brevis, Lb plantarum, Ln mesenterö̈des, Candida krusei & \\
\hline Tempe (tempeh) & Indonesiae & Beans, cereals & Rhizopus ssp. & Spontaneous \\
\hline Olive & $\begin{array}{l}\text { Italy, Greece, } \\
\text { Turkey }\end{array}$ & Olive & Ln, Pediococcus, Lb plantarum & Spontaneous \\
\hline Pickles & Turkey & Cucumber & Lb plantarum, Lb pentosaceus, Ln mesenteroides, Pc cerevisiae & $\begin{array}{l}\text { Spontaneous or natural } \\
\text { starters }\end{array}$ \\
\hline Rabadi & India & Barley, buttermilk & & Spontaneous \\
\hline Selroti & Himalayas & $\begin{array}{l}\text { Rice, maize, } \\
\text { millet, ... }\end{array}$ & $\begin{array}{c}\mathrm{LAB} \\
\text { (Ln mesenteroïdes, Ec faecium, Pc pentosaceus, Lb curvatus), } \\
\text { Saccharomyces cerevisiae, S. kluyveri, } \\
\text { Debaryomyces hansenii, Pichia }\end{array}$ & Spontaneous \\
\hline Injear & Ethiopia & Sorgo, tef & $\mathrm{LAB}$ & Spontaneous \\
\hline Ekung, eup, hirring & India & Bamboo shoots & $\begin{array}{l}\text { Lb plantarum, } L b \text { brevis, } L b \text { casei, } L b \\
\text { fermentum, Lactococcus, Tetragenococcus }\end{array}$ & Spontaneous \\
\hline Gundruk, khalpi & Nepal & $\begin{array}{l}\text { Cabbage, mustard } \\
\text { and radish leaves }\end{array}$ & LAB (Lb plantarum, Lb brevis, Lb pentosaceus) & Spontaneous \\
\hline
\end{tabular}

faces). Processing conditions may influence the microbial composition, especially the temperature and duration of the fermentation [38]. Vera et al. (2012) [39] studied a French sourdough over ten successive days. The microflora was mainly composed of LAB ( $>8 \log (\mathrm{cfu}) / \mathrm{g})$ and, at lower levels, yeasts $(<7 \log (\mathrm{cfu}) / \mathrm{g})$. The dominant Lactobacillus population included four different species. The key function of $L b$ frumenti and $L b$ panis was the synthesis of aromatic compounds whereas the key function of Lb acetotolerans and Lb amylolyticus was acidification. These original microbial consortia cooperate and form nutritional, trophic or metabolic collaborations, such as Lactobacillus sanfranciscensis and Candida humilis or Lb plantarum and Saccharomyces cerevisiae [28]. Bacteria, which become active as the fermentation begins, release fermentable sugars into the medium. Yeasts can use these sugars for their growth [4]. For example, the ability of Lb sanfranciscensis to break down maltose in glucose allows the yeast $S$. exiguous to develop, which then produces free amino acids. These amino acids, in turn, stimulate the growth of Lb sanfranciscensis [16].

\subsubsection{Natural Starter Dynamics}

The backslopping methodology tends to favour the bacterial community which is the best adapted to the environmental conditions that prevail at a given time [40]. Dalmasso (2009) [25] and Demarigny et al. (2011) [34] showed that the acidification potential of Lacotococcus in model whey starters was prone to change from one 
day to the next. This was also observed in a goat cheese model: the proteolytic properties and acidifying activities of Leuconostoc strains seemed to become greater and greater as a consequence of backslopping. Thus the starter acquires a type of "specificity" very quickly. The whey is an open system in which bacteria adopt a planktonic behaviour; as such, they can move freely, as a result of Brownian movement, for instance. Exchanges and associations between bacteria should, then, be promoted. As a result, LAB may gain or lose phenotypic characteristics through gene exchanges, e.g. via prophages [25] [41], plasmids or DNA transfers (transduction, bacterial conjugation) [42]. However, in a model system, we did not observe any plasmid transfer between Lactococcus strains or different genus (Enterococcus and Lactococcus, [34]). If strains lost enzymatic abilities, they did not gain new characteristics as a result. Unlike bacteria in biofilms, the liquid structure of NS is probably less favourable to gene transfers and molecular communication [43].

As such, other mechanisms are probably in play which leads to rearrangements between the different microbial populations. For instance, it has been reported that in sourdough, the practice of backslopping led to the progressive disappearance of Saccharomyces cerevisiae owing to both its inability to catabolise maltose and its sensitivity to LAB acetic acid [16]. LAB can apply various strategies. The sturdiness and reactivity of LAB to different stresses have also been studied [44]. The backslopping practice is continuously putting pressure on LAB. Concerning the quick changes in Lactococcus characteristics (decrease of the potential to acidify, loss of phenotypic characteristics) in a whey starter described above, this modification (phages being absent) may correspond to the selection of the most adapted strains. Thus Lactococcus could gradually develop specific features in a natural starter environment. At strain level, in the fresh whey of Scamorza cheese, Baruzzi et al. (2002) [45] observed that Streptoccus thermophilus C48W accounted for more than $40 \%$ of the strains present. However, 24 hours later, the dominance was shared by two strains: C48W and C24W. It was supposed that C48W was more opportunistic at the beginning of the fermentation while C24W, being more acid-resistant, prevailed at the end.

A natural starter, like all ecosystems is highly complex. This means that it is unpredictable per se, out of control and cannot be completely described [45]. However, these structures are spontaneously self-organising which makes them flexible, autonomous and hardy. This enables them to cope with internal and external perturbations. But it also allows them to generate original properties, meaning that a NS is never reduced to the sum of all its individual parts. From a physical point of view, it follows that NS could be considered as continuous sets instead of discrete sets. This complexity would, then, be a selective asset in evolutionary terms [2]. A NS is never stable, even if apparently no changes are observed. From an ecological point of view, this is called a climax state. We can then wonder whether LAB populations in NS could adopt a structural state analogous to that of microbial populations in the gut ecosystem. In this case, Doré and Fortier (2010) [46] proposed to distinguish two different microbial states: the normabiose refers to the normal state of the gut, whereas the dysbiose corresponds to the introduction of specific gaps with the normabiose. As a consequence, a normabiose could be associated with a "good" NS (according to our vision of normality...) whereas the dysbiose would lead to "incorrect" NS and, thereafter, inappropriate products (cheeses, breads, ...). The difficulty is that a NS re-creates its normality incessantly. As such, a dysbiose is not necessarily recognised as a disequilibrium, but as a consequence of our incapacity to qualify normality and to allow this concept to evolve as fast as NS. This reflection poses a fundamental question: what are we trying to discover when we study NS? So long as we are unable to formalise our research goals precisely, we will never understand NS evolution.

\subsubsection{Influence of NS on the Dynamics of Fermented Products}

Like NS, uncooked fermented products are alive and are constantly changing. During product making, microorganisms are subject to many forms of stress. Stress leads to the activation of regulatory mechanisms in the microbial metabolism [47]. Different metabolic pathways which may be responsible for the sensory quality of the products are then solicited [48].

In milk, whey and all the fermented beverages, microorganisms are potentially mobile. On the contrary, in a solid matrix (cheeses or sausages), they cannot move any longer since they are definitively trapped during moulding. Bacteria are organized in "motionless" microcolonies forming clusters. Microcolonies are microecosystems in themselves, because this kind of spatial organization favours local interactions. This microbial distribution can explain, for instance, the spatial heterogeneity of a cheese [49]. Depending on the environmental conditions, successions of different bacterial genus are able to develop or decline. Mesophilic lactobacilli for example grow during the cheese ripening stage, while populations of Lactococcus and Leuconostoc decrease and the population of Enterococcus remains steady [25]. Raw milk flora (and especially Lactobacilli), which are al- 
most always detected at low levels in whey, develop in cheeses and participate in the ripening [50]. These microflora can overwhelm the other microorganisms thanks to their robustness. During ageing, the physicochemical conditions of the product change as a consequence of extrinsic (temperature, humidity, air flow) or intrinsic factors (bacterial activity, endogenous or added enzymes). This creates different gradients (ammoniac, $\mathrm{pH}$, oxygen, ...) which influence the microbial dynamics of growth and survival. The succession of bacterial communities reflects the temporal (diachronic dimension) and the spatial (synchronic dimension) heterogeneity of the final product [50]. The microbial complexity resulting from the backslopping practice is then "transformed" by the selective pressure exerted by the medium and the processing conditions. In a sense, NS can be considered as a source of bacterial diversity (or a reserve of adaptability) in which the most adapted bacteria are always selected, whatever the microenvironment of the final product [51].

\subsection{Sensory Consequences}

Fermented products have particular sensory characteristics (taste, odour, texture) owing to the combined and complementary actions of the great diversity of microorganisms.

The sensory profile of sourdough bread partly depends on lactic (produced by homofermentative lactobacilli) and acetic acids (only produced by heterofermentative lactobacilli) concentrations [52]. Acids modify the gluten structure, which can be rather elastic (if lactic acid is favoured) or brittle (acetic acid), and thus the consistency of the bread. Corsetti and Settanni (2007) [16] reported that a majority of homofermentative LAB led to an increased production of diacetyle and aldehydes in the sourdough. A majority of heterofermentative bacteria led to the production of ethyl and hexyl acetate. Specific flavours are generated by secondary proteolysis, a bacterial catabolism which leads to the release of free amino acids from macropeptides. Amino acids can be aromatic compounds in themselves - i.e. sulphur amino acids—or at the root of aromatic compounds (keto acids, alcohols, esters, etc.) [16]. Arginine, for example, is influential in the development of the crust aroma [53]. The association of bacteria and yeast helps to increase the aromatic diversity of breads [54]. Sourdough breads have a longer shelf-life than bread made only with yeasts. Indeed, it goes stale less rapidly due to the presence of exopolysaccharides (EPS) produced by LAB. Lb sanfranciscensis is well-known for its ability to synthetise high quantities of EPS [16]. EPS enhance water retention and play the role of hydrocolloids. Therefore, the inside of the bread keeps its sensory quality over a longer period of time; in particular, it is more elastic compared with yeast bread [15]. Alveoli are also irregular.

NWS contribute to the development of flavour and texture in cheeses during ripening owing to the wide proteolitic capacities of the LAB [55]. Caseins are broken down into peptides and amino acids. The latter can be converted thereafter into $\alpha$-keto acids. These molecules are precursors of many aromatic compounds such as aldehyde, carboxylic acid and alcohols [56]. The citrate metabolism produces several molecules, among them acetic acid and diacetyle, a molecule exhibiting a buttery and nutty aroma. LAB lipolysis is quite marginal but contributes to the liberation of volatile fatty acids after autolysis of the cells.

Dalmasso (2009) [25] made the hypothesis that backslopping concentrated plasmin, an enzyme mainly responsible for the breaking down of $\beta$-casein (and to a lesser extent $\alpha_{\mathrm{s} 1}$-casein), and rennet in whey. Plasmin is naturally combined with casein micelles in a complex enzymatic system. The decrease in $\mathrm{pH}$ favours the dissociation of this complex and the concomitant release of plasmin in the whey. Each backslopping step makes the plasmin (and the rennet) a little more concentrated in the whey starter. Indeed, after a 4-month ageing, $\beta$ and $\alpha_{\mathrm{S} 1}$ casein concentrations in Tome like cheeses were two times lower between the first and the tenth day of backslopping: this decrease was linear from day to day [25]. As a consequence, cheeses appeared less and less bitter and more and more elastic. Bitterness in cheese is linked with accumulation of bitter peptides and therefore to an unbalanced proteolysis [56]. Increasing primary proteolysis by concentrating plasmin and rennet and secondary proteolysis probably contributed to improving the sensory balance (texture and bitterness) of cheeses made with NWS.

\subsection{Biopreservation}

Biopreservation refers to food protected by the presence of indigenous microorganisms against pathogenic or spoiling microorganisms. Biopreservation covers many different possibilities, and among them the hurdle concept (barrier effect), the use of phages or the release of antimicrobial substances by positive bacteria (bacteriocins for instance) [57]. The stakes around biopreservation greatly differ depending on which food technology is 
used and the sensitivity of the product to microbial contaminations. For example, heating or cooking (bread, hard and pasteurized cheese) destroys most of the vegetative pathogenic bacteria, such as Listeria monocytogenes and Salmonella enterica. However, thermic treatments do not wipe out spores (Bacillus, moulds) or toxins (Staphylococcus aureus). Spoiling bacteria can be tolerated as long as they remain at low levels, but pathogenic bacteria must be completely absent from the food (as defined in the European Community 2073/2005 regulation). As a consequence, biopreservation means taking into account all the factors that could favour or deplete the action of positive microbes: type of product (raw materials, food making, etc.), characteristics of undesired microflora (growth rates, growth conditions, resistances, etc.) and the anticipated result (inhibition of growth, of the production of toxins, eradication) [29].

Fermentation is a very ancient way to protect a raw material naturally over time. Fermentation creates harsh conditions for many microorganisms because of $\mathrm{pH}$ decrease, organic acid production (lactic acid, acetic acid) and potential diminution of redox. Generally, food safety is guaranteed as soon as the pH reaches 4.2 or below [4]. The synergic effect of lactic acid and low $\mathrm{pH}$ contribute to the partial inhibition of many pathogenic bacteria; this is the case with Listeria monocytogenes [58] and Salmonella enterica [59]. Natural starters participate in food protection either by competing for nutritional resources (for example Staphylococcus aureus as referred to by [60]) or by the production of inhibitory compounds (organic acids, hydrogen peroxide) and/or antimicrobial compounds (bacteriocins). Demarigny (unpublished results) observed that more than 80\% of the LAB isolated from a NWS used to make an artisanal goat milk cheese presented inhibition capabilities. This observation is consistent with the idea that in an open environment, competition is strong. Only the microorganisms which possess selective capabilities are expected to survive [16]. But more complex bioprotective effects can also be observed [29]. The anti-Listeria action of bacterial communities (LAB and others) in cheese has been frequently studied (on the surface of washed-rind cheeses; on Comté cheese ripening wood boards, on the surface and inside Saint-Nectaire cheeses). Individually, the strains isolated from these cheeses do not exert any inhibition on the growth of Listeria. The collective action of the community is far more important than the individual action of each population taken separately. The positive inhibitory effect of the community manifests itself through the emergence of a global effect which encompasses bacterial interactions inside the community. Hitherto these interactions have remained largely unknown [29]. In this sense, the use of NS is preferable to individual strains.

Microbial diversity generally allows NS to adapt better in the case of sudden environmental changes and better resist phage attacks [55]. Indeed, Ly-Chatain et al. (2011) [61] observed the coexistence of phage and LAB (Lactococcus) populations, both at high levels, in natural whey starters. From another point of view, volatile amino acids released during proteolysis can also contribute to bread protection. Lbplantarum and Lbsanfranciscensis release phenyllactic acid from phenylalanine. This compound is known to exhibit antifungal properties in sourdoughs. As these acids are thermo-stable, bread is also more resistant to fungal attacks [16].

\section{Context, Stakes and Issues around Natural Starters Nowadays}

As natural starters are complex, the use of back-slopping is a delicate issue, which relies upon several factors. Some of these factors are strongly influenced by slight differences while others are more robust. It was shown for instance that a $2^{\circ} \mathrm{C}$ difference in the incubation temperature of a NWS is enough to modify the biochemical characteristics of a hard cheese [62]. Concerning farm house made cheeses, the back-slopping practice is very empirical [31]. Milk incubation (with a NS, a practice called "prématuration” in goat milk cheese technology) is essential for the subsequent acidification. The quantity of NS added must be precisely adapted: an excess of NWS leads to an excess of acidification and the resulting curd exhibits defects. The inoculation temperature also plays an important role: too high $\left(16^{\circ} \mathrm{C}\right)$ and $E$. coli and other coliforms can grow; too low $\left(8^{\circ} \mathrm{C}\right)$ and $\mathrm{LAB}$ activity is slowed down and acidification is weaker. The acidification step is essential for the success of the cheese making, and acidification depends on NS microflora, both quantitatively and qualitatively. If the final $\mathrm{pH}$ is not correct or the aspect of the curd is not in compliance with the one desired, the cheese maker may decide to change his NS [31]. When farmers face recurrent problems, a lot of them tend to swap the back-slopping practice for industrial starters, which are more stable and easier to use. In some cases, they decide to put an end to their cheese production.

Changes in practices-beyond the technical constraints inherent with the use of natural starter-can be highlighted by new ways of consuming. The large-scale retailer sector and consumption are very cautious about food safety and regularity in food quality [31]. Tolerance levels concerning the appearance of food have grown nar- 
rower (except for direct selling). Fabrication defects lead unerringly to economic losses as result of the time wasted, the loss of raw materials and, even more importantly, of consumer trust.

The issues natural starters raise are different depending on a country's economic development. In developed countries, technological and financial matters prevail, while in developing countries, hygienic concerns dominate over all other factors. Fermentation allows foods to be protected from undesirable pathogenic bacteria on condition that basic hygienic rules are followed, like Good Manufacturing Practices (GMP) [4]. Spore forming bacteria, such as Bacillus cereus, can survive difficult conditions and so resist through the fermentation step [6]; GMP can prevent the appearance of this pathogen. The use of selected starters must be handled quite cautiously. In developed countries, the typicality of a fermented product and its link to its "terroir" are in contradiction with standardization. Standardized products display reproducible flavours from one batch to the next. This is important for many consumers and, generally, these products are cheaper. While traditional foods display less constancy in term of sensory characteristics, and are frequently more expensive, they are unique. In many tropical countries where pathogenic pressure is greater, the microbial diversity found in the natural starters is a way of protecting fermented food products. Standardization through the use of industrial starters (which are generally composed of a limited number of strains) could here lead to sanitary risks [6].

Today, in people's minds, safety, good sensory characteristics and typicality are more and more important and have to be linked together. Products fermented with natural starter are usually known to be typical of a given region, made according to an ancient know-how using (but not systematically) the technique of back-slopping and naturally protected from contamination. Thus, they can perfectly respond to this new consumer demand. The originality of a fermented product is associated amongst other things with a specific microflora [63]. For Protected Geographical Status, microorganisms are part of the specifications and are considered either as distinctive features of processing or of the geographical site of production. However, proof that a link between microorganisms and the typicality of local fermented products exists, is still required to assert this hypothesis. The influence of whey back-slopping on typicality, sensory properties, and the biopreservation abilities of cheese has never been studied, although some pioneering articles have pointed the way [25]. The main reason for this lack is the difficulty to totally understand complex microbial ecosystems (starters), especially the dynamics at play between the different microorganisms. However, over the last few years new methods to study microbial ecosystems, called the global molecular approach (high-flow sequencing), have been developed [29]. It is permitted to think that in the future, some of the factors which cause the product to take root in a particular terroir will be deciphered. And among them, NS will probably prove to be fundamental.

The ability to provide a precise description of a microbial ecosystem is currently a major stake. A better understanding of natural starter ecosystems would help to improve back-slopping fermentation. Indeed, these technological aspects are essential, yet the know-how and the culture associated to this practice have to be preserved as well. The increasing knowledge about natural starter could lead to a form of "domestication" of these wild bacteria well-adapted to their environment. Original wild strains could be included in industrial starters because of their ability to adapt [49]. At the present time, we can wonder whether the genetic diversity of industrial starters will increase or not. Can we be sure that the genetic potentiality of local strains will be preserved over time if they are dissociated from their primary microbial ecosystems?

\section{Acknowledgements}

The authors would like to thank Carl Holland for English revision.

\section{References}

[1] Roger, C. (2013) La qualité et la sécurité sanitaire des produits alimentaires: Un des enjeux du Millénium Round de l’OMC. Internet Département Economie et Sociologie Rurales-INRA. http://www.inra.fr/sae2/comprendre/js/qualite.php

[2] Demarigny, Y. (2013) Les écosystèmes microbiens fromagers. Ph.D. Dissertation, UCBL1, Lyon.

[3] Scintu, M.F. and Piredda, G. (2007) Typicity and Biodiversity of Goat and Sheep Milk Products. Small Ruminant Research, 68, 221-231. http://dx.doi.org/10.1016/j.smallrumres.2006.09.005

[4] Holzapfel, W.H. (2002) Appropriate Starter Culture Technologies for Small-Scale Fermentation in Developing Countries. International Journal of Food Microbiology, 75, 197-212. http://dx.doi.org/10.1016/S0168-1605(01)00707-3 
[5] Hansen, E.B. (2002) Commercial Bacterial Starter Cultures for Fermented Foods of the Future. International Journal of Food Microbiology, 78, 119-131. http://dx.doi.org/10.1016/S0168-1605(02)00238-6

[6] Demarigny, Y. (2012) Fermented Food Products Made with Vegetable Materials from Tropical and Warm Countries: Microbial and Technological Considerations. International Journal of Food Science and Technology, 47, 2469-2476. http://dx.doi.org/10.1111/j.1365-2621.2012.03087.x

[7] Lonvaud-Funel, A. (2008) Du raisin au vin: L'activité d’un système microbien dynamique. Biofutur, 294, 26-29.

[8] Leroy, F. and De Vuyst, L. (2004) Lactic Acid Bacteria as Functional Starter Cultures for the Food Fermentation Industry. Trends in Food Science and Technology, 15, 67-78. http://dx.doi.org/10.1016/j.tifs.2003.09.004

[9] Froc, J. (2005) Nomadisme et sédentarisation: De l'airag au soja natto, du sapsago au vin jaune. In: Montel, M.C., Béranger, C. and Bonnemaire, J., Eds., Les fermentations au service des produits de terroir, INRA Editions, Paris, 39-46.

[10] Steinkraus, K.H. (2002) Fermentations in World Food Processing. Comprehensive Review in Food Science and Food Safety, 1, 23-32. http://dx.doi.org/10.1111/j.1541-4337.2002.tb00004.x

[11] FAO (2011) Current Status and Options for Biotechnologies in Food Processing and in Food Safety in Developing Countries. In: Biotechnologies for Agricultural Development, Proceedings of the FAO International Technical Conference on "Agricultural Biotechnologies in Developing Countries: Options and Opportunities in Crops, Forestry, Livestock, Fisheries and Agro-Industry to Face the Challenges of Food Insecurity and Climate Change”, ABDC-10, 240-277.

[12] Neuzil, E. and Devaux, G. (1999) Le koumys, hier et aujourd'hui. Bulletin de la Société de Pharmacie de Bordeaux, 138, 91-112.

[13] Buckenhüskes, H.J. (1993) Selection Criteria for Lactic Acid Bacteria to Be Used as Starter Cultures for Various Food Commodities. Federation of European Microbiological Societies Microbiology Reviews, 12, 253-271. http://dx.doi.org/10.1016/0168-6445(93)90067-J

[14] Hwanhlem, N., Buradaleng, S., Wattanachant, S., Benjakul, S., Tani, A. and Maneerat, S. (2011) Isolation and Screening of Lactic Acid Bacteria from Thai Traditional Fermented Fish (Plasom) and Production of Plasom from Selected Strains. Food Control, 22, 401-407. http://dx.doi.org/10.1016/j.foodcont.2010.09.010

[15] INPB (1996) Levains et Panification. Les Nouvelles de la Boulangerie Pâtisserie, Supplément Technique, 54.

[16] Corsetti, A. and Settanni, L. (2007) Lactobacilli in Sourdough Fermentation. Food Research International, 40, 539-558. http://dx.doi.org/10.1016/j.foodres.2006.11.001

[17] Demarigny, Y., Sabatier, C., Laurent, N., Prestoz, S., Rigobello, V. and Blachier, M.J. (2006) Microbiological Diversity in Natural Whey Starters Used to Make Traditional Rocamadour Goat Cheese and Possible Relationships with Its Bitterness. Italian Journal of Food Science, 18, 261-276.

[18] Bouton, Y., Guyot, P. and Grappin, G. (1998) Preliminary Characterization of Microflora of Comté Cheese. Journal of Applied Microbiology, 85, 123-131. http://dx.doi.org/10.1046/j.1365-2672.1998.00476.x

[19] Rossetti, L., Fornasari, M.E., Gatti, M., Lazzi, C., Neviani, E. and Giraffa, G. (2008) Grana Padano Cheese Whey Starters: Microbial Composition and Strain Distribution. International Journal of Food Microbiology, 127, 168-171. http://dx.doi.org/10.1016/j.ijfoodmicro.2008.06.005

[20] Coppola, S., Parente, E., Dumontet, S. and La Peccerella, A. (1988) The Microflora of Natural Whey Cultures Utilized as Starters in the Manufacture of Mozzarella Cheese from Water-Buffalo Milk. Lait, 68, 295-309. http://dx.doi.org/10.1051/lait:1988319

[21] Ercolini, D., Moschetti, G., Blaiotta, G. and Coppola, S. (2001) The Potential of a Polyphasic PCR-DGGE Approach in Evaluating Microbial Diversity of Natural Whey Cultures for Water-Buffalo Mozzarella Cheese Production: Bias of Culture-Dependent and Culture-Independent Analyses. Systematic and Applied Microbiology, 24, 610-617. http://dx.doi.org/10.1078/0723-2020-00076

[22] Baruzzi, F., Matarante, A., Morea, M. and Cocconcelli, P.S. (2002) Microbial Community Dynamics during the Scamorza Altamurana Cheese Natural Fermentation. Journal of Dairy Science, 85, 1390-1397.

[23] Ercolini, D., Frisso, G., Mauriello, G., Salvatore, F. and Coppola, S. (2008) Microbial Diversity in Natural Whey Cultures Used for the Production of Caciocavallo Silano PDO Cheese. International Journal of Food Microbiology, 124, 164-170. http://dx.doi.org/10.1016/j.ijfoodmicro.2008.03.007

[24] Laithier, C., Raynaud, S. and Bonnes, A. (2012) Contribuer à la performance technico-économique des exploitations fromagères fermières en améliorant la maîtrise technologique et la qualité des fromages. Innovations en Agronomie, 25, 269-282.

[25] Dalmasso, M. (2009) Etude de l'influence du repiquage sur la complexité des lactosérums levains. Application aux modèles fromagers de type pâte pressée non cuite et de type mixte à dominante lactique. Ph.D. Dissertation, Université 
de Chambéry, Savoy.

[26] Baruzzi, F., Matarante, A., Morea, M. and Cocconcelli, P.S. (2002) Microbial Community Dynamics during the Scamorza Altamurana Cheese Natural Fermentation. Journal of Dairy Science, 85, 1390-1397. http://dx.doi.org/10.3168/jds.S0022-0302(02)74206-9

[27] Salvadori del Prato, O. (2002) Bacterial and Technological Diversity: Interaction. Congrilait, Paris.

[28] Vrancken, G., Rimaux, T., Weckx, S., Leroy, F. and de Vuyst, L. (2011) Influence of Temperature and Backslopping Time on the Microbiota of a Type I Propagated Laboratory Wheat Sourdough Fermentation. Applied and Environmental Microbiology, 77, 2716-2726. http://dx.doi.org/10.1128/AEM.02470-10

[29] Zagorec, M., Champomier-Vergès, M., Renault, P., Valence, F., Le loir, Y. and Montel, M.C. (2012) Ecosystèmes microbiens et préservation des aliments. Innovations en Agronomie, 24, 57-77.

[30] Dalmasso, M., Prestoz, S., Rigobello, V. and Demarigny, Y. (2008) Evolution of the Raw Cow Milk Microflora, Especially Lactococci, Enterococci, Leuconostocs and Lactobacilli over a Successive 12 Day Milking Regime. International Journal of Dairy Science, 3, 117-130. http://dx.doi.org/10.3923/ijds.2008.117.130

[31] Laithier, C., Chatelin, Y.M., Tormo, H. and Lefrileux, Y. (2004) Biofilms in Farms Producing Goat Cheese: Localisation, Nature and Role on Products Quality. In: Actes des 11ème Rencontres Recherche Ruminant, Paris, 11-12.

[32] Vacheyrou, M., Normand, A.C., Guyot, P., Cassagne, C., Piarroux, R. and Bouton, Y. (2011) Cultivable Microbial Communities in Raw Cow Milk and Potential Transfers from Stables of Sixteen French Farms. International Journal of Food Microbiology, 146, 253-262. http://dx.doi.org/10.1016/j.ijfoodmicro.2011.02.033

[33] Callon, C., Duthoit, F., Delbès, C., Ferrand, M., Le Frileux, Y., De Crémoux, R. and Montel, M.C. (2007) Stability of Microbial Communities in Goat Milk during a Lactation Year: Molecular Approaches. Systematic and Applied Microbiology, 30, 547-560.

[34] Demarigny, Y., Dalmasso, M., Tonleu, A., Rigobello, V., Beuvier, E., Ly-Chatain, M.H. and Bouton, Y. (2011) Influence of the Backslopping Practice on the Microbial Diversity of the Lactococcus Population in a Model Cheesemaking. Food and Nutrition Sciences, 2, 618-627. http://dx.doi.org/10.4236/fns.2011.26087

[35] Desmasures, N. and Beuvier, E. (2011) Chapitre 1: Ce qu'il faut savoir avant d'intervenir sur les microflores des laits. I. Nature et quantité de microflores des laits. In: Microflores des laits, Réseau Fromages de terroir, Paris, 4-14.

[36] Lazzi, C., Rossetti, L., Zago, M., Neviani, E. and Giraffa, G. (2004) Evaluation of Bacterial Communities Belonging to Natural Whey Starters for Grana Padano Cheese by Length Heterogeneity-PCR. Journal of Applied Microbiology, 96, 481-490. http://dx.doi.org/10.1111/j.1365-2672.2004.02180.x

[37] Rossetti, L., Fornasari, M.E., Gatti, M., Lazzi, C., Neviani, E. and Giraffa, G. (2008) Grana Padano Cheese Whey Starters: Microbial Composition and Strain Distribution. International Journal of Food Microbiology, 127, 168-171.

[38] Arendt, E.K., Ryan, L.A.M. and Dal Bello, F. (2007) Impact of Sourdough on the Texture of Bread. Food Microbiology, 24, 165-174. http://dx.doi.org/10.1016/j.fm.2006.07.011

[39] Vera, A., Ly-Chatain, M.H., Rigobello, V. and Demarigny, Y. (2012) Description of a French Natural Wheat Sourdough over 10 Consecutive Days Focussing on the Lactobacilli Present in the Microbiota. Antonie van Leeuwenhoek, 101, 369-377. http://dx.doi.org/10.1007/s10482-011-9642-6

[40] Zambonelli, C., Chiavari, C. and Benevelli, M. (2003) Starter microbici naturali e selezionati per la produzione di alimenti fermentati. Industrie Alimentari, 42, 617-623.

[41] Salama, M.S., Musafija-Jeknic, T., Sandine, W.E. and Giovannoni, S.J. (1995) An Ecological Study of Lactic Acid Bacteria: Isolation of New Strains of Lactococcus Including Lactococcus lactis Subspecies cremoris. Journal of Dairy Science, 78, 1004-1017. http://dx.doi.org/10.3168/jds.S0022-0302(95)76716-9

[42] Kelly, B.G., Vespermann, A. and Bolton, D.J. (2009) Gene Transfer Events and Their Occurrence in Selected Environments. Food and Chemical Toxicology, 47, 978-983. http://dx.doi.org/10.1016/j.fct.2008.06.012

[43] Nataïli, M. and Briandet, R. (2013) Les cités microbiennes. Biofutur, 3, 24-27.

[44] van de Guchte, M., Serror, P., Chervaux, C., Smokvina, T., Ehrlich, S.D. and Maguin, E. (2002) Stress Responses in Lactic Acid Bacteria. Antonie van Leeuwenhoek, 82, 187-216. http://dx.doi.org/10.1023/A:1020631532202

[45] Heylighen, F. (2008) Complexity and Self-Organization. In: Encyclopedia of Librairy and Information Sciences, Taylor \& Francis, London, 1-20.

[46] Doré, J. and Corthier, G. (2010) Le Microbiote Intestinal. Gastroentérologie Clinique et Biologique, 34, 7-10. http://dx.doi.org/10.1016/S0399-8320(10)70002-6

[47] Cretenet, M., Laroute, V., Ulvé, V., Jeanson, S., Nouaille, S., Even, S., Piot, M., Girbal, L., Le Loir, Y., Loubière, P., Lortal, S. and Cocaign-Bousquet, M. (2011) Dynamic Analysis of the Lactococcus lactis Transcriptome in Cheeses Made from Milk Concentrated by Ultrafiltration Reveals Multiple Strategies of Adaptation to Stresses. Applied and Environmental Microbiology, 77, 247-257. http://dx.doi.org/10.1128/AEM.01174-10 
[48] Suzzi, G. (2011) From Wild Strain to Domesticated Strain: The Philosophy of Microbial Diversity in Foods. Frontiers in Microbiology, 2, 169. http://dx.doi.org/10.3389/fmicb.2011.00169

[49] Giraffa, G. (2004) Studying the Dynamics of Microbial Populations during Food Fermentation. FEMS Microbiology Reviews, 28, 251-260. http://dx.doi.org/10.1016/j.femsre.2003.10.005

[50] Cogan, T.M., Beresford, T.P., Steele, J., Broadbent, J., Shah, N.P. and Ustunol, Z. (2007) Invited Review: Advances in Starter Cultures and Cultured Foods. Journal of Dairy Science, 90, 4005-4021.

[51] Angelier, E. (2008) Les Sciences de la complexité et le vivant. Tec \& Doc, Paris.

[52] Vera, A. (2011) Etude de l'écosystème levain de panification. Incidence de l'échelle de fermentation sur la composition physico-chimique et microbiologique des levains. Ph.D. Dissertation, University Claude Bernard Lyon 1, Lyon.

[53] de Vuyst, L., Vrancken, G., Ravyts, F., Rimaux, T. and Weckx, S. (2009) Biodiversity, Ecological Determinants, and Metabolic Exploitation of Sourdough Microbiota. Food Microbiology, 26, 666-675. http://dx.doi.org/10.1016/j.fm.2009.07.012

[54] Meignen, B., Onno, B., Gelinas, P., Infantes, M., Guilois, S. and Cahagnier, B. (2001) Optimization of Sourdough Fermentation with Lactobacillus brevis and Baker’s Yeast. Food Microbiology, 18, 239-245. http://dx.doi.org/10.1006/fmic.2000.0395

[55] Reinheimer, J.A., Quiberoni, A., Tailliez, P., Binetti, A.G. and Suárez, V.B. (1996) The Lactic Acid Microflora of Natural Whey Starters Used in Argentina for Hard Cheese Production. International Dairy Journal, 6, 869-879. http://dx.doi.org/10.1016/0958-6946(96)00014-3

[56] Smit, G., Smit, B.A. and Engels, W.J.M. (2005) Flavour Formation by Lactic Acid Bacteria and Biochemical Flavour Profiling of Cheese Products. FEMS Microbiology Reviews, 29, 591-610. http://dx.doi.org/10.1016/j.fmrre.2005.04.002

[57] Montel, M.C., Bouton, Y. and Parguel, P. (2012) Ecosystèmes des laits et des fromages au lait cru-Enjeux pour leur maîtrise. In: Actes des 13ème Rencontres Recherche Ruminant, Paris.

[58] Millet, L., Saubusse, M., Didienne, R., Tessier, L. and Montel, M.C. (2006) Control of Listeria monocytogenes in Raw-Milk Cheeses. International Journal of Food Microbiology, 108, 105-114. http://dx.doi.org/10.1016/j.ijfoodmicro.2005.11.004

[59] Fayol-Messaoudi, D., Berger, C.N., Coconnier-Polter, M.H., Liévin-Le Moal, V. and Servin, A.L. (2005) pH-, Lactic Acid-, and Non-Lactic Acid-Dependent Activities of Probiotic Lactobacilli against Salmonella enterica Serovar Typhimurium. Applied and Environmental Microbiology, 71, 6008-6013. http://dx.doi.org/10.1128/AEM.71.10.6008-6013.2005

[60] Haines, W.C. and Harmon, L.G. (1973) Effect of Selected Lactic Acid Bacteria on Growth of Staphylococcus aureus and Production of Enterotoxin. Applied Microbiology, 25, 436-441.

[61] Ly-Chatain, M.H., Durand, L., Rigobello, V., Vera, A. and Demarigny, Y. (2011) Direct Quantitative Detection and Identification of Lactococcal Bacteriophages from Milk and Whey by Real-Time PCR: Application for the Detection of Lactococcal Bacteriophages in Goat's Raw Milk Whey in France. International Journal of Microbiology, 2011, Article ID: 594369. http://dx.doi.org/10.1155/2011/594369

[62] Demarigny, Y., Poizat, M., Huguet, M., Le Coq, H. and Guegen, M. (2004) Evolution de la composition de la flore lactobacille thermophile cultivée sur lactosérum cru au cours de fabrications successives de fromages à pâte pressée cuite dure. 12 ème Club des Bactéries Lactiques, Aurillac.

[63] Capozzi, V. and Spano, G. (2011) Food Microbial Biodiversity and "Microbes of Protected Origin”. Frontiers in Microbiology, 2, 237. 
Scientific Research Publishing (SCIRP) is one of the largest Open Access journal publishers. It is currently publishing more than 200 open access, online, peer-reviewed journals covering a wide range of academic disciplines. SCIRP serves the worldwide academic communities and contributes to the progress and application of science with its publication.

Other selected journals from SCIRP are listed as below. Submit your manuscript to us via either submit@scirp.org or Online Submission Portal.
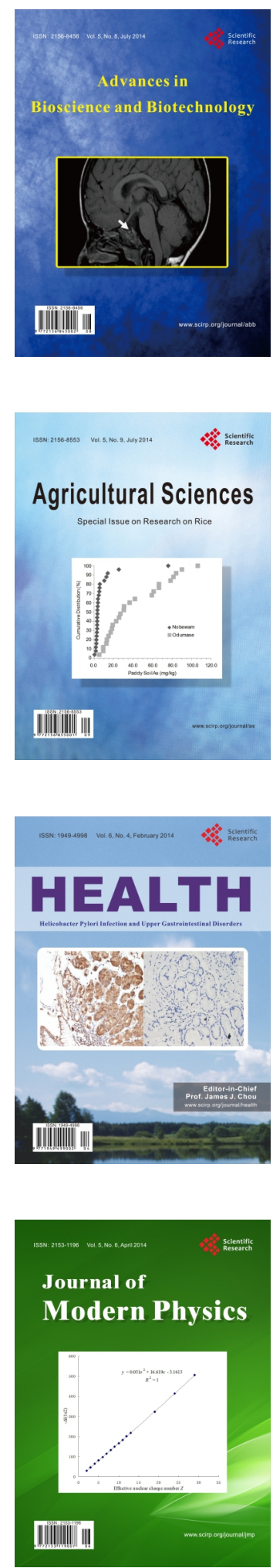
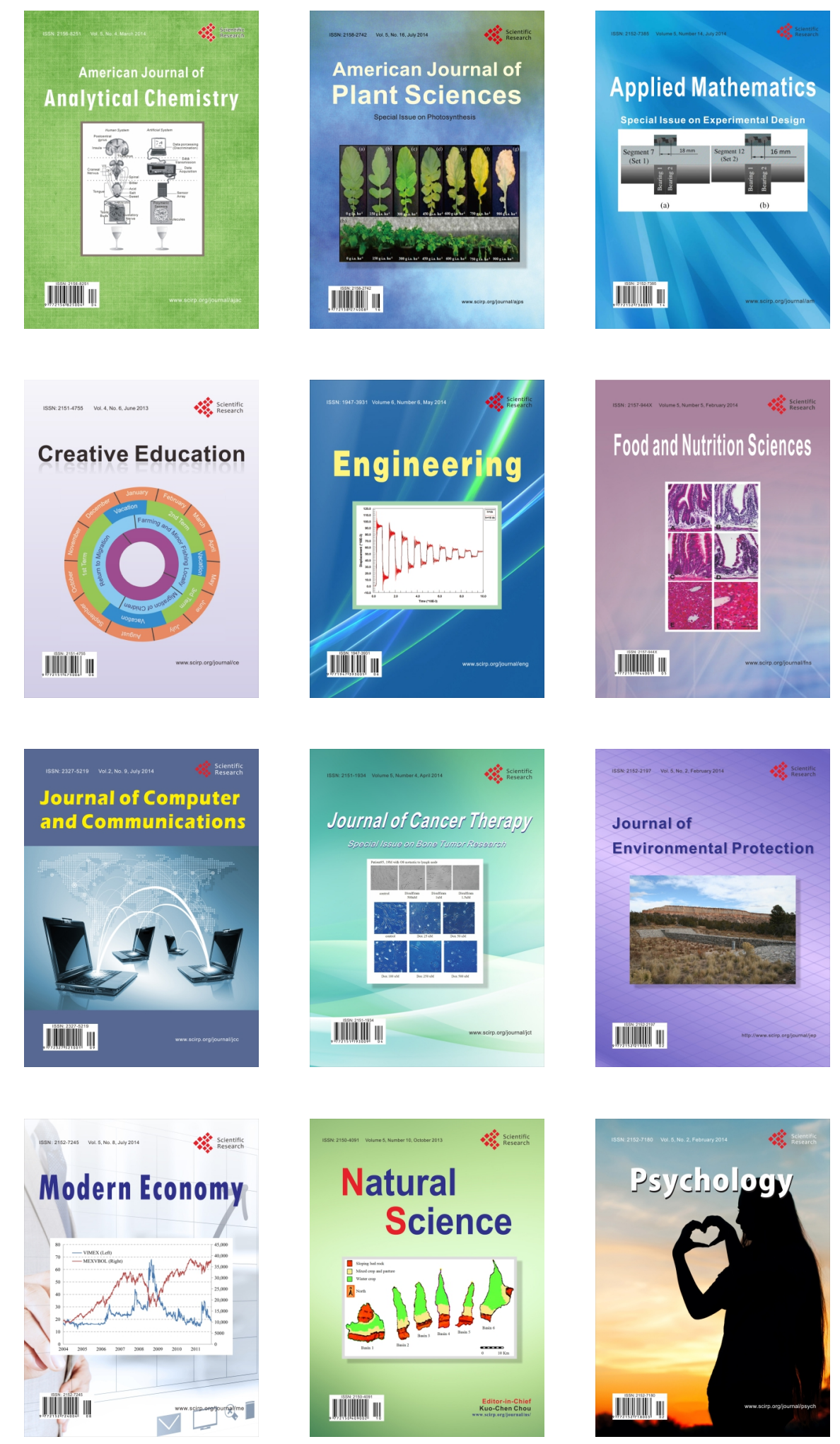